\title{
Incorporating Community Governance: Planning Sustainable Energy Security
}

\author{
Diane Costello, Curtin University of Technology, Western Australia, \\ Australia
}

\begin{abstract}
Climate change has focussed global attention on reducing greenhouse gas (GHG) emissions, particularly through energy efficient technological innovation. In Australia energy policy incentives include increasing the contribution of renewable energy sources along with energy efficient behaviours. In Western Australia an Energy Utility has embraced the principle of community engagement to inform corporate strategies toward sustainable green energy visions. This paper evaluates the process of citizen involvement in promoting community acceptance of green energy technologies at the community level. This qualitative study examines the role of community governance in planning the sustainable energy needs of regional communities. While it is promising to observe the emergence of flexible institutional responses to community energy visions, this energy governance network is a work in progress as it struggles to gain community consensus to site a small community-owned wind farm. To address community polarisation over the costs and benefits of community energy, attention must be paid to issues of inclusive representation along with mechanisms of accountability that assesses the social and economic impacts of green energy initiatives. This study highlights that an effective governance process would incorporate the principles of sustainability, procedural and distributive justice to enhance community transitions toward a more environmentally benign economy and electricity system.
\end{abstract}

Keywords: Sustainability Planning, Community Engagement, Deliberative Democracy, Decentralized Renewable Energy Sustainable Energy Planning, Procedural and Distributive Justice Community Energy

\section{Climate Change \& Energy}

$\mathrm{A}$

LL BUT THE most extreme contrarians accept that, whatever happens to future greenhouse gas (GHG) emissions, we are now locked into irreversible climate change patterns (IPCC, 2007; Zillman, McKibbin \& Kellow, 2005). While Australian contribution to global greenhouse gas emissions is only $1.6 \%$, the nation's per capita emissions are the highest in the developed world (Kent \& Mercer, 2006). This is attributed to a number of reasons: (a) cheap electricity and therefore efficiencies are not encouraged; (b) the economy is heavily reliant on energy intensive industries; (c) a declining use of renewable energy, (d) a high level of land clearing, (e) a strong reliance on brown and black coal; and (f) the population of Australia is highly dispersed, leading to a high energy requirement for transportation (Kent \& Mercer 2006).

Many of these points apply to Western Australia, where minerals and petroleum account for $80 \%$ of the state's exports and around $94 \%$ of electricity is generated from coal and natural gas (SEDO, 2008). Not only does Australia have a moral obligation to find solutions to mitigate source causes of climate change, it also has a strong vested interest. To enable socially just and environmentally sound responses, the IPCC endorses local participatory processes that incorporate broader conceptions of lifestyle choices that go beyond individual or tech-

The International Journal of Environmental, Cultural, Economic and Social Sustainability C $O M M O N$ Volume 7, 2011, http://www.Sustainability-Journal.com, ISSN 1832-2077 
nological solutions to more fundamental alternative courses for our collective futures (Aylett, 2010; Banuri et al., 2001; Munasinghe and Swart, 2005). This paper examines how participatory governance has been used by a Power Utility in Western Australia to plan a collective path toward a reliable and sustainable energy supply. The objective of this paper is to examine and evaluate the public participation approach adopted by representatives of a Power Utility to plan sustainable energy visions that reflect the goals of diverse regional communities.

\section{Contribution of Decentralised Generation \& Renewable Energy}

A changing climate seriously challenges our socio-political and economic systems (Aylett, 2010). To respond to the twin challenges of climate change and energy security, governments worldwide have focussed on the development of more efficient and environmentally friendly energy resources as a pressing objective (Allen et al, 2007). Indeed, renewable energy (RE) development has emerged as a common and significant component of national greenhouse gas (GHG) reduction efforts (Kelly, 2006). Combined with renewable energy sources, decentralization of power generation is expected to make a significant contribution to climate protection (Owen, 2006). Energy management is thus a changing paradigm as the role of distributed energy (locally generated power) gains significance in liberalized electricity markets.

According to Martin et al. (2008) several factors have dictated a gradual shift to a more decentralised layout where distributed generation (DG) technologies (small generators typically ranging from $1 \mathrm{~kW}$ to $10 \mathrm{MW}$ ) provide electricity where it is needed. While many factors underlie the push toward DG, priority concerns are for future security and quality of supply and the environmental issues related to the use of fossil fuels. Also significant is that decentralised energy generation can play a major role in advancing renewable sources of energy for meeting the electricity needs of remote and regional communities (McKenzie \& Howes, 2006; Hammons, 2008). In social and environmental terms, the benefits include reducing emissions of air pollutants, including greenhouse gas (GHG), increasing employment opportunities and strengthening the economy by effective and sustainable utilization of local resources (Zahnd \& McKay, 2009).

\section{New Governance-Prospects for Community Planning}

In Australia contemporary strategies for rural development are based on notions of individual and community responsibility, which mobilize the skills and resources of the local community (Herbert-Cheshire, 2000, 2003; Little, 2001). The shift towards new, advanced liberal forms of governance (Edwards, 2001) highlights the extent to which governing styles have moved away from the formal, coercive powers of government towards a new form of governing that involves a partnership between state and non-state actors (Head \& Ryan, 2004). In regional Australia, civil society sectors (voluntary civic and social organizations and institutions) are proactively engaged in local governance networks to address social, environmental and economic issues (Costello \& Bishop, 2008; 2009). In fact Australia plays a leading role in advancing the social mobilization approach to natural resource management (Alston, 2002; Wilson, 2004). As electricity generation has far-reaching social, economic and environmental implications, McKenzie and Howes (2006) emphasize the essential role of local decision making to enhance community resilience and technological transformation. 
To plan a sustainable energy vision for two regional communities vulnerable to energy poverty, the Officers of a Power Utility instigated a community engagement forum. This involved the invitation of purposefully selected stakeholders to participate in a power working group to design plans for energy generation and energy efficiency. The main author was invited to capture the engagement process and evaluate the possibility that this deliberative process may serve as a model for other community engagement forums. The theory of deliberation, specifically Abelson et al.'s (2003) principles for the design and evaluation of public participation processes informs the assessment of the Power Utility's community engagement initiative to plan the future energy needs of regional communities.

\section{Theory on Deliberation-Participatory Principles}

As a comprehensive review of the political theory of deliberation is beyond the scope of this paper, key principles useful to the analysis of the public participation activities undertaken by the Power Utility is reviewed. Carson \& Hartz-Karp (2005) highlight three principles that a public engagement exercise should be: (a) highly representative, (b) deeply deliberative and (c) extremely influential. If a public engagement exercise is highly representative then a diverse group would be gathered together, usually through random selection, to reflect the viewpoints of a cross-section of the population. Public engagement is deeply deliberative when it is based on open dialogue and reasoned discussion. Most importantly it will be free from domination, under the watchful eye of a skilled, neutral facilitator whose sole role is to enable the group to find its own way (Carson, 2009).

Carson \& Hartz-Karp (2005) emphasize that deliberation is not debate; as dialogue and deliberation are the better alternatives for the resolution of intractable problems. Carson (2009) also informed that participants in deliberation do not need to reach consensus or achieve unanimity because minority opinions can be recorded, but the movement toward 'common ground', which include exposure of conflicts, is important for an effective deliberative process.

As a social process, authentic deliberation relies on persuasion to induce participants' reflection on and altering of views (Dryzek, 2000; Przeworski, 1998; Cohen, 1989). Hence, participants need to influence each other and to influence the decision maker (Carson \& Hartz-Karp, 2005). According to Carson (2009) deliberation involves three criteria which are interdependent and interrelated. For example, without an evident pathway from consultation to influence, it is difficult to attract a highly inclusive sample to engage in deliberation. Without a very inclusive sample, the process will lack credibility amongst those who should be influenced and so on. Failure to meet any of these three criteria typically causes the process to flounder, and it can have a compounding, negative effect in terms of the other criteria (Carson and Hartz-Karp, 2005).

Abelson et al.'s (2003) principles for the design and evaluation of public participation processes incorporate four dimensions: (a) representation; (b) procedural rules; (c) information and (d) outcomes/decisions. Table 1 depicts the conceptual framework underpinning the criteria that guide the assessment of the deliberative process and outcomes. 
Table 1: Abelson et al.'s (2003) Evaluative Criteria

\begin{tabular}{|c|c|c|c|}
\hline Representation & Procedural Rules & Information & Outcomes/ Decisions \\
\hline $\begin{array}{l}\text { Legitimacy and } \\
\text { fairness of selection } \\
\text { process }\end{array}$ & $\begin{array}{l}\text { Degree of citizen } \\
\text { control/input into: } \\
\text { agenda setting, } \\
\text { establishing rules, } \\
\text { selecting experts, } \\
\text { information }\end{array}$ & $\begin{array}{l}\text { Characteristics: } \\
\text { Accessibility } \\
\text { Readability } \\
\text { Digestibility } \\
\text { Selection and } \\
\text { presentation }\end{array}$ & $\begin{array}{l}\text { Legitimacy and } \\
\text { accountability of: } \\
\text { Decision-making } \\
\text { Communication of } \\
\text { decisions } \\
\text { Responses to decision or } \\
\text { input } \\
\text { More informed citizenry }\end{array}$ \\
\hline \begin{tabular}{|l} 
Is there a \\
representative \\
sample? \\
Geographic \\
Demographic \\
Political \\
Community
\end{tabular} & $\begin{array}{l}\text { Deliberation } \\
\text { Amount of time } \\
\text { Emphasis on } \\
\text { challenging } \\
\text { experts, } \\
\text { information } \\
\text { Mutual respect }\end{array}$ & $\begin{array}{l}\text { Who chooses the } \\
\text { information } \\
\text { Who chooses the } \\
\text { experts }\end{array}$ & \\
\hline $\begin{array}{l}\text { Participant selection } \\
\text { vs. Self-selection } \\
\text { Inclusiveness } \\
\text { (broad) } \\
\text { Vs Exclusiveness } \\
\text { (narrow) }\end{array}$ & $\begin{array}{l}\text { Credibility/legitimacy } \\
\text { of process } \\
\text { What point in the } \\
\text { decision-making } \\
\text { process is input being } \\
\text { sought? } \\
\text { Who is listening? (e.g. } \\
\text { Influential } \\
\text { decision-makers } \\
\text { or junior staff) }\end{array}$ & $\begin{array}{l}\text { Interpretation } \\
\text { Adequacy of time } \\
\text { provided to } \\
\text { consider, } \\
\text { discuss and } \\
\text { challenge the } \\
\text { information }\end{array}$ & $\begin{array}{l}\text { Achievement of } \\
\text { consensus over the } \\
\text { decision } \\
\text { (i.e. Broad-based } \\
\text { understanding and } \\
\text { acceptance of } \\
\text { final decision) } \\
\text { Better (or different) } \\
\text { decisions }\end{array}$ \\
\hline
\end{tabular}

\section{Power Relations \& Civil Ethic of Engagement}

Protagonists contend that communicative rationality is inherent in citizen empowerment at the local level (Sagoff 1988; Gundersen 1995; Healey 1996) and it is said to constitute deliberative democracy and sustainability. In response social theorists challenge the presumption that power relations can be excluded from the deliberative dialogue and that status inequality among participants can be reduced in the pursuit of the common good (Hindess, 1996; Elkin 1985; Bachrach \& Baratz, 1962). In resolve, Stratford, Armstrong and Jaskolski (2003) contend that without an applied ethic of engagement the process may be subject to vested interests and various forms of political favouritism. To address conflicts in communities, they suggest the alternative model of agonistic pluralism to negotiate the dominance of vested interests. Citing Mouffe (2000) agonistic pluralism involves a "civil ethic of engagement supportive of the principles of democracy to which parties adhere, even while they remain adversarial-agonistic rather than merely antagonistic, understanding the need for substantive (though not irreconcilable) dissent and not mere procedural consensus underpinned by ongoing enmity"(no page, see Stratford, Armstrong \& Jaskolski, 2003). 
Although the benefits of incorporating deliberative elements into public policy decisionmaking process may be broadly accepted, the processes and outcomes need evaluation to ensure that the voices of the less powerful are represented. This paper discusses the effectiveness of the Power Utility's community engagement process based on the principles of the deliberative evaluative framework articulated previously.

\section{Case Study Communities}

This study evaluated the effectiveness of a Power Utility's community engagement process to plan the energy visions of two regional communities (referred to as Community ' $A$ ' and ' $B$ '). These two coastal rural communities are located on the south west coast of Western Australia more than $400 \mathrm{~km}$ from the capital city of Perth. Energy reliability is a major concern for regional communities located at the edge of the main electricity grid. Most problematic are the frequency of power outages that can occur during peak demand periods and when the tourism season can lead to a doubling of the population causing surges in electricity demand.

To address these concerns the Utility representatives instigated a community energy forum to obtain local input and to placate community negativity over the social and economic costs of power outages. The Utility Agency's officers convened a "power working group" by inviting key stakeholders from two communities to deliberate over the ideal energy source and technology mix required to meet the future needs of the respective communities. A total of 14 representatives participated comprising of 11 residents from Community ' $A$ ' and 3 residents from Community 'B'.

Noteworthy is that these two Shire aligned representatives differ significantly on a number of characteristics. Firstly, Community 'A's representatives are politically active and include high profile environmentalists possessing pertinent expertise with advocacy and sustainable energy development. Community ' $\mathrm{B}$ ' representatives on the hand have limited experience with energy technology and are more development oriented with expertise in local government management. The disparity in numbers representing each community also contributed to an unequal power status that impeded the quality of community engagement for Community $\mathrm{B}$ which will be elaborated on at a later stage.

\section{Qualitative Methodology}

This qualitative research design is based on a triangulation (Madill et al., 2000) of data sources: (a) observational evidence; (b) historical information from archival analysis, and (c) interview and survey data from community informants. A qualitative approach is most appropriate for gaining a contextually grounded understanding of the research domain (Lincoln \& Guba, 2000; Sandelowski, 2000). As the researcher had previous research experience with the regional communities, trust was established to proceed with the evaluation of this community forum.

\section{Interview \& Survey Participants}

Using purposeful (Patton, 1990; Williams \& Lewis, 2005) and theoretical sampling techniques (Punch, 1998), 25 interviewees with key community stakeholders and representatives from 
the power working-group were selected for an in-depth interview. Procedures for interviews involved semi-structured, open-ended interviews that were tape-recorded and transcribed verbatim. Interviews ceased on reaching saturation point of issues emerging (Glaser \& Strauss, 1967). The procedures for survey participants involved an email request being sent to 14 community representatives of the power working group and 12 respondents returned completed surveys ( 10 from Community 'A' and 2 from Community ' $\mathrm{B}$ ').

\section{Coding \& Analysis of Qualitative Data-Grounded Theory}

To undertake thematic analysis, the methodology was informed by grounded theory. Grounded theory is inductively derived and verified through systematic data collection and analysis of data pertaining to that phenomenon (Hall \& Callery, 2001; Strauss \& Corbin, $1990 ; 1998)$. Through the process of emergence codes and categories were generated directly from the transcribed interview data (Glaser, 1978; 1992) by the researcher and two colleagues independently of each other. This followed axial coding where relationships among the core set of categories are linked to produce higher-level categories (Miller \& Fredericks, 1999; Pandit, 1996). Emergent theory was then compared to other literature and perspectives to capture broader insights and to validate or point out differences or gaps in current understandings (Pope-Davis, et al., 2002). While drawing conclusions from a single case study is inherently risky (Lawrence, 2002) validity is enhanced through informant verification and when emergent theory is compared to existing theory (Glaser, 1998).

\section{Analysis of Themes}

The coding process revealed four overarching themes categorized as (1) SustainabilityPrinciples Underlying Energy Visions; (2) Sense of Community and Geographic Affinity; (3) Pull-Push Socio-Political Factors and (4) Local Governance Dynamics. For pragmatic purposes the discussion following focuses on sub-themes related to the effectiveness of local governance dynamics to plan for a secure and reliable energy supply that fits with the core principles of sustainability.

\section{The Green Agenda-Power \& Issues of Representation}

As previously noted this 'power working group' selected and assembled by the Power Agency officers largely comprise of green oriented social activists from Community 'A' and this group worked tirelessly to steer the sustainable energy agenda as an imperative to deal with the threats of climate change. As a result the forums largely focussed on solutions identified by Community ' $A$ ' to reduce energy consumption through energy efficiency strategies and increasing the role of renewable energy generation. While all representatives supported green strategies it was not motivated solely by environmental concerns. For a small group of representatives not subscribing to green politics, it was a pragmatic decision supported on the premise that it was economically viable and advantageous to the business image.

While this power working-group pursued feasibility planning for green energy solutions to meet future needs, the procedural process began to reveal signs of instability. For example, during forum deliberations Community ' $\mathrm{B}$ ' representatives verbalized high levels of agitation over the low priority given to their energy solutions. Although their criticisms were acknow- 
ledged, the facilitation process did not redress the uneven power dynamics and opportunities for procedural fairness were missed. While numerous factors are related to Community B's concerns over the conduct of the forum, the issue of uneven representation triggered their dissatisfaction with the community engagement process.

In direct contrast, the majority of Community 'A's representatives acknowledged the positive role played by the Utility's officer in changing the power relationship between institution and community. The bold move taken by the energy Utility to incorporate local expertise into the planning process represents a major cultural shift in governance relations between Utility and community. Community 'A' was equally satisfied with the facilitation process as it provided these representatives with ample opportunities to participate in informed discussions. However, this positive perception can be attributed to the utility Officers inexperience with facilitation that allowed the more powerful Community 'A's representatives (which included a Greens Member of Parliament) possessing high level energy expertise to steer the deliberation process.

The power dynamics were never explicitly addressed, combined with the effect of Community B's minority status and minimal access to energy expertise, feelings of resentment and disempowerment surfaced. In terms of the effectiveness of the deliberative process, outcomes can be described as mixed. For the more powerful members the process was deeply deliberative, it involved open dialogue and reasoned discussion that influenced others, particularly the decision makers. In contrast, for the less powerful members, deliberation was a highly frustrating experience. The process was predominantly seized by more powerful vested interests as management by a skilled and neutral facilitator was not present. Despite majority endorsement that effective deliberation had been achieved, the disempowering experience of a minority group had been missed despite their vocalization to disengage from the deliberative process. As McGuirk convincingly advised, "power and difference are impossible to set aside, and the idea that subjects can step outside the power grids that constitute them in order to reflect rationally, knowingly, and communicatively upon them" (2001, p. $213)$ is in dispute.

\section{Validity of Decision Making-Procedural Issues}

Even with the best intentions of the Utility representatives, the effectiveness of the deliberative process revealed that they are in the early stages of the learning curve with regard to both distributed energy technologies and the community engagement process. The consequence is that the deliberative process has compromised the validity of this power workinggroup to make decisions on behalf of the whole community. Firstly, the soundness of the participant selection process appeared problematic, as the Utility officers pre-determined the composition of the stakeholders invited as community representatives. The membership can be described as 'the usual suspects' or citizen/elite stakeholders-government and nongovernment organizational representatives, environment groups, local council representatives and energy researchers and experts. Not surprisingly this selection process did not result in a representative sample reflective of the broader social mix of geographic, demographic and political community. The group assembled to make energy decisions affecting the future sustainability of the community were heavily biased by green oriented representatives. More importantly those who could challenge the decisions specifically the business development 
oriented members and those directly affected by the decisions are at best minimal. Diverse representation was not actively pursued.

The procedural aspects of the forum also challenge the validity of this group's energy visions. For example, the bi-monthly meetings were always held in 'Community A' which is more than an hour's drive from Community B. The forum was held during the working week and this precluded the participation of the working residents and the business sector. Also challenging the soundness of the procedural process is that the meetings were always chaired by the Utility officers and the agenda was also set by them. These officers also largely took responsibility for choosing the visiting experts and the format of information presented. While the community representatives had minimal input into the organizational operation of this power forum, the officers allowed the deliberation process to be steered by the more knowledgeable representatives due to their lack of expertise with this new venture.

A pertinent illustration which questions the validity of this power working group's decisions involves the development of a community-owned wind farm in Community A. This project was endorsed by the Utility as a sound investment to develop locally generated green power. While the power working group supported the wind farm, this project was challenged by other powerful groups in the community. This community wind farm project began four years earlier as a highly contentious issue involving debate at national and state governments, including community level over its proposed development. While its construction is now supported by the majority of community constituents there is deep division over site selection located on pristine coastal landscape. The mismatch of goals between the power working group and the larger community is exemplified by the Local Council's decision to reject outright the site selected for the construction of this community wind farm. In fact the Local Council had initially congratulated the developers for securing Commonwealth government funds for this project however they subsequently rejected the development due to growing political differences related to site selection. As Carson and Hartz-Karp (2005) highlighted without a very inclusive sample, the process will lack credibility amongst those who should be influenced.

\section{Representation and Restrictive Deliberative Frameworks}

While a number of factors can be attributed to the rejection of this wind farm project, a key factor is that the Power Utility's community engagement process failed to secure a highly representative sample to support the decisions of this power working group. For example, had more diverse representatives participated or at the very least, wider community feedback been gained about the overall strategic energy visions, the wind farm project may have become a less contentious issue. Diverse consultation may have revealed the dissenters, particularly those who opposed it on the grounds that it would curtail economic development. Had the deliberative process revealed the issues underlying the disputes then a more holistic decision making process would have emerged to address concerns raised. As Wolsink (2007) noted "If local interests are not given a voice in decision-making processes, conditional supporters may turn into objectors" (p. 2694).

Lacking diverse representation, the deliberative process while considered successful among the green oriented representatives was not able to move toward common ground at the larger community level. Had the social and economic concerns of the opposing groups been represented and addressed through procedural fairness this initiative may have become less contro- 
versial for the community. Carson (2009) indicated that consensus is not necessary however an effective deliberation process must include exposure of conflicts to provide the opportunity to understand it, in order to move respectfully.

Representatives of the power working group are also divided about the validity of their strategic energy visions for the community as a whole. As they highlighted, although they reflect the majority community's principled commitment toward green energy innovations, they do not necessarily represents the needs and aspirations of the diverse groups in terms of promoting sustainable energy reliability and security. In this vein Reid (2009) eloquently revealed that "sustainable governance and solutions will require managers to focus more on ecological principles and systems theory to achieve more synergistic solutions for the complex problems we face (p. 29). The author emphasized that a community initiative meeting multiple sustainability gaols would integrate promotion of energy conservation with the reduction of utility bills for low-income homeowners. From this perspective the power working group representatives are highly aware that the deliberative process warranted change. As they indicated, feedback and follow-up with the diversity of community interests was largely lacking, as they are not informed about community reactions to the energy initiatives planned and implemented by the power working group.

Another key issue associated with good governance is that the power working group's deliberations did not embrace the wider social and economic implications of green energy visions. The framework which guided the deliberative process was constrained by the Power Utility's regulatory, economic and statutory concerns. These constraints overshadowed social concerns and the process precluded consideration of the wider community needs and priorities including impacts. Hence the process fixated on substantive goals to plan energy strategies while procedural goals of inclusiveness, egalitarianism and multi-stakeholder participation were missed. Adopting a sustainability framework which promotes balance between economic development, social equity and environmental protection based on inclusionary governance would redress this weakness (Agyeman \& Evans, 2004; Szarka, 2004). As a socially responsible decision making framework would lead to substantive goals that is representative and accountable to the larger community as well as meet sustainability aspirations (Kolk, 2008; Reid, 2009).

Constrained by regulatory barriers, a restrictive procedural framework and a lack of diverse representation, the deliberative process prohibited recognition of dissent and the conception of multiple sustainability visions. Adopting an ethical framework with structures that allows more holistic discussions of social, economic, environmental and governance impacts of its decisions is one way forward. Mouffe (2000) eloquently illustrated: "the expression of hegemony and the crystallization of power relations and the outcome of debate will be contingent upon particular regimes of inclusion and exclusion". To create spaces for dissent Stratford, Armstrong and Jaskolski (2003) suggest the practice of agonistic pluralism which makes explicit the power differentials in society and acknowledges the productive potential of conflict and democratic compromise. The challenge then becomes one of "creating methods of deliberation and decision making that actively engage the relevant interests and communities in thinking through and deciding upon the kind of future they want to try and create" (Robinson, 2004, page 380). 


\section{Community Awareness \& Institutional Change}

In spite of the limitations experienced by this community engagement process a number of key positive outcomes have emerged. The participation of the Power Utility officers at the local community level is a powerful symbol of institutional change toward democratic local governance. Community interviews also revealed that local community engagement has increased levels of trust between the Utility officers and the community as it has engendered a positive working relationship with the majority of the community representatives. As the participants highlighted, having direct access to government officials to voice community concerns reduced the level of negative community attitude towards the Power Utility's response to energy reliability issues. In reviewing the benefits of local governance, Geiselhart (2004) and O'Hara (2004) confirm that public trust is related more to reputation and experiences derived from direct forms of participation and engagement.

An important and significant outcome of this community engagement process is that it has sparked many other community initiatives to promote awareness, education and easy access to information and advice to reduce energy consumption and deploy local generation of renewable energy (RE). Some of the key representatives of community 'A' have been proactive in encouraging a community-wide approach to climate change adaptation. There has also been intense lobbying of state politicians to reduce regulatory and institutional barriers to deploy decentralized forms of RE generation and increase the funding for demand side management strategies (e.g. energy efficiency). At the socio-political level this power working group has been highly effective in promoting the cultural transformation of mindsets in government institutions toward development of distributed RE initiatives. This community engagement process has enabled this power working group to use its human, social and political capital to effect change at individual, community and higher societal levels.

This positive outcome however has been overshadowed by the procedural aspects of the deliberative process as it failed to address the uneven power dynamics between group members. This enabled the more powerful members a voice over their visions and priorities while the less powerful group felt excluded from the decision-making process. O'Neill (1997) poignantly argued that conflicts are not only about values, they are also about power and interests. Reducing inequities in power are often a necessary pre-requisite or an integral component of initiatives demanding inter-group cooperation (Calderon, 2000; McIntyre, 2004). Addressing power inequity will require change to the existing structure of the forums to enable the less powerful a voice. Not only will it require skilled and independent facilitation but it will also require more input from diverse groups to ensure procedural justice for all.

The success of the community engagement process in terms of the validity of its energy visions for the community is also ambiguous. For example, in terms of effecting wider community influence, it appears that this 'power working group' over-estimated the level of community acceptance of their strategic direction toward local RE generation to reduce reliance on coal-fired power. Had the process involved more diverse representation then the social and economic implications of its green energy visions would have been debated. As a symbol of democratic local governance this power working-group will need to implement a number of procedural changes to ensure that deliberations are monitored by a trained facilitator; guided by ethical sustainability frameworks and that their decisions are legitimate and accountable. 


\section{Conclusion and Discussion}

A significant outcome of this community engagement approach is that its planning process can be judged as more democratic than centralised expert management (Nelson et al., 2008). To continue with the design of local policy, procedural changes are vital to ensure that the substantive decisions made by the power working group are valid and accountable. While deliberations empowered representatives of Community ' $A$ ' to develop plans for its green energy innovations, Community ' $\mathrm{B}$ ' was frustrated by the uneven power dynamics that restricted maximum participation. Nevertheless, the energy Utility representatives embraced community engagement with enthusiasm in the spirit of mutual social learning. While many socio-political and economic benefits have been realized, not surprisingly many mistakes have also been made. To address the limitations, this power working-group adopted many changes to ensure greater control by community representatives and diverse representation.

This evaluation lead to structural changes to enable procedural fairness, involving the rotation of the location of the meetings along with rotational chairs to include greater community members' involvement in agenda setting. Although the energy Utility officers' over-reliance on this power work-group meant that they thought it was meeting its obligation to consult with 'the community' this research has highlighted modifications that are vital to ensure inclusivity and validity of the decision-making process as well as to effect wider community influence and acceptance of strategic planning with the community.

While this community engagement process empowered the politically savvy stakeholders, the less powerful ultimately demanded redress. In view of this, community engagement practitioners need to be vigilant to power differences and ensure that skillful facilitators are engaged to promote inclusive participation; address status inequalities and ensure representation of diverse community interests. Also significant is adopting an ethical deliberative framework that enables social learning, spaces for dissent and discussions that incorporate the broader social, economic, environmental and governance concerns and impacts.

Despite the mixed outcomes community governance facilitated cultural mindset changes at the institutional level to respond to community aspirations for a transition toward low emission energy technological solutions. Also significant is that this community power working-group is leading the way in promoting local generation of renewable energy sources including strategies to reduce consumption and effect behavioural changes to reduce greenhouse gas emissions at the community level. While the deliberative process will require changes to incorporate inclusive representation and decision-making frameworks that are accountable, this power working-group has worked with the energy Utility planners to identify the path toward cost effective technological solutions that can deliver a reliable and secure energy supply that does not compromise the planet.

Dryzek (1990) writes

"The assumptions of representative democracy have been progressively undermined by the scale and complexity of contemporary societies and their rate of change. Elected representatives can rarely capture the diverse values and social and economic interests of their constituents, while the uncertainties generated by novel threats argue for the inclusion of a wide range of knowledges in decision making" 
In view of the complexity inherent in democratic enterprise, Stagl (2006) summons us to perceive decision making as an adaptive process where actors are involved in a continuous social learning process. According to Webler, Kastenholz and Renn (1995) social learning refers to changes in popular awareness and changes in how individuals see their private interests linked with the shared interests of their fellow citizens. "Social learning occurs when individuals learn how to solve their shared problems in a manner that is responsible to both, factual correctness and normative consent (meaning legal and social responsibilities)" (Webler, et al., 1995, cited in Stagl, 2006, p. 54).

From this perspective the community engagement initiative can be considered a work in progress where social actors are engaged in social learning to plan the energy source and technology mix desired for its respective communities that fits with legal and social responsibilities. Social scientists therefore can play a key role in critiquing and evaluating the contribution of deliberative engagement as a catalyst for change at community and societal levels to address issues of local and global concern. More research is vital to understand the socio-economic and political factors that enhance and impede the successful transition toward low emission energy solutions. Imperative also is the integration of the moral and civic contribution of 'civil society' through community engagement as it is vital to sustain institutions' effectiveness in ensuring social justice and equity for all (Pandey, 2009; Stubbs \& Cocklin, 2008). To promote a just process toward a sustainable energy future it is imperative that decision making frameworks are evaluated against contextual considerations: such as culture, politics, geographic location, landscape and other sustainability considerations (Benecke, 2008; Lowe \& Lloyd, 2001; Nelson et al., 2008). Otherwise we are gullible to the uncritical acceptance of the ideology of sustainability and democracy. 


\section{References}

Abelson, J., Fores, P-G., Eyles, J., Smith, P., Martin, E. \& Gauvin, F-P. (2003). Social Science \& Medicine, 57, 239-251.

Allen, S.R., Hammond, G.P. \& McManus, M.C. (2007). Prospects for and barriers to domestic microgeneration: A United Kingdom perspective. Applied Energy, 85, 528-544.

Agyeman, J. \& Evans, B. (2004). 'Just sustainability': the emerging discourse of environmental justice in Britain? The Geographical Journal, 170(2), 155-164.

Alston, M. (2002). Social Capital in Rural Australia. Rural Society, 12(2), 93-104.

Arendt, H. (1958). The human condition. Chicago: University of Chicago Press.

Aylett, A. (2010). "Conflict, collaboration, and climate change: participatory democracy and urban environmental struggles in Durban, South Africa”. International Journal of Urban and Regional Research, 34(4), 99-115.

Bachrach, P., \& Baratz, M. (1962). Two faces of power. American Political Science Review, 57(4), 947-952.

Banuri, T., Wyant, J., Akumu, G., Najam, A., Pinguelli, Rosa L., Rayner, S., Sachs, W., Sharma, R., Yohe, G., Agarwal, A., Bernow, S., Costanza, T., Downing, T., Kartha, S., Khosla, A., Sagar, A., Robinson, J., Toth, F. (2001). Setting the stage: climate change and sustainable development, In: Climate Change 2001: Mitigation, Report of Working Group III, Intergovernmental Panel on Climate Change, Cambridge University Press: Cambridge.

Benecke, G.E. (2008). Success factors for the effective implementation of renewable energy options for rural electrification in India-Potentials of the Clean Development Mechanism. International Journal of Energy Research, 32, 1066-1079.

Calderon, E. J. (2000). An applied method for the assessment of sustainability of urban pilot projects. Environmental Impact Assessment Review, 20, 289-298.

Carson, L. (2009). Deliberative public participation and hexachlorobenzene stockpiles. Journal of Environmental Management 90, 1636-1643.

Carson, L., Hartz-Karp, J., 2005. Adapting and combining deliberative designs: juries, polls, and forums. In: Gastil, J., Levine, P. (Eds.), The Deliberative Democracy Handbook: Strategies for Effective Civic Engagement in the 21st Century. Jossey-Bass, San Francisco, CA, pp. 120-138.

Cohen, J. (1989). Deliberation and democratic legitimacy. In A. Hamlin, \& P. Pettit (Eds.). The good polity: normative analysis of the state (pp. 17-34). Oxford: Basil Blackwell.

Costello, D. \& Bishop, B. (2009). Community Sustainability \& Social Justice: Whose Justice? The International Journal of Environmental, Cultural, Economic \& Social Sustainability, 5(1), 141-160.

Costello, D. \& Bishop, B. (2008). Searching for Social Justice-Decentralized Governance \& Rural Community Sustainability. Journal of Contemporary Issues in Business and Government, 14(1), 81-106.

Dryzek, J. S. (2000). Deliberative democracy and beyond. Oxford: Oxford University Press.

Dryzek, J. (1990). Discursive Democracy: Politics, Policy and Political Science. Cambridge University Press, Cambridge.

Edwards, M. (2001). Public sector governance-future issues for Australia. Australian Journal of Public Administration, 61(2), 51-61.

Elkin, S. L. (1985). Economic and Political Rationality. Polity, 18(2), 253-271.

Geiselhart, K. (2004). Digital Government and Citizen Participation Internationally. Pavlichev, A. and Garson, G. D. (Eds.) Digital Government: Principles and Best Practises. Hershey: Idea Group Publishing.

Glaser, B.G. (1998). Doing Grounded Theory: Issues and Discussions. Mill Valley, CA: Sociology Press.

Glaser, B.G. (1992). Basics of Grounded Theory Analysis: Emergence versus forcing. Mill Valley, CA: Sociology Press. 
Glaser, B.G. (1978). Theoretical sensitivity: Advances in the Methodology of Grounded Theory. Mill Valley, CA: Sociology Press.

Glaser, B.G. \& Strauss, A.L. (1967). The discovery of grounded theory: Strategies for qualitative research. Chicago, IL: Aldine.

Gundersen, A. (1995). The environmental promise of democratic deliberation. University of Wisconsin Press, Madison.

Hall, W.A. \& Callery, P. (2001). Pearls, Pith, and Provocation, Enhancing the Rigor of Grounded Theory: Incorporating Reflexivity and Relationality. Qualitative Health Research, 11(2), 257-272.

Hammons, T.J. (2008). Integrating renewable energy sources into European grids. Electrical Power and Energy Systems, 30,462-475.

Head, B. \& Ryan, N. (2004). Can co-governance work? Regional natural resource management in Queensland, Australia. Paper presented at International Symposium on Public Sector Management, Budapest, 31 March-2April, 2004.

Healey, P. (1996). The communicative turn in planning theory and its implication for spatial strategy formation. Environment and Planning B Planning and Design, 23, 217-34

Herbert-Cheshire, L. (2003). Translating policy, power and action in Australia's country towns. Sociologia Ruralis, 43(4), 454-473.

Herbert-Cheshire, L. (2000). Contemporary strategies for rural community development in Australia: a governmentality perspective. Journal of Rural Studies, 16, 203-215.

Hindess, B. (1996). Discourses of power: From hobbes to foucault. Oxford and Cambridge, MA: Blackwell Publishers.

IPCC. (International Panel on Climate Change). (2007). The Physical Science Basis. Summary for Policymakers. Contribution of Working Group 1 to the Fourth Assessment Report of the Intergovernmental Panel on Climate Change. Approved by IPCC WGA, Paris, February 2007. Retrieved March 30, 2008, http://www.ipcc.ch/SPM2feb07.pdf

IPCC. (2000). "IPCC Special Report: emissions scenarios", in: A Special Report of IPCC Working Group III, Nakicenovic, N. \& R Swart, R. (Eds.). Intergovernmental Panel on Climate Change: Geneva.

Kelly, G. (2006). Renewable energy strategies in England, Australia and New Zealand. Geoforum, 38, $326-338$.

Kent, A. \& Mercer, D. (2006). Australia's mandatory renewable energy target (MRET): an assessment. Energy Policy, 34, 9, 1046-1062.

Kirby, A. (2004). Britons unsure of climate costs. BBC News Online, at: http://news.bbc.co.uk/1/hi/sci/tech/3934363.stm; full poll results also available at http://news.bbc.co.uk/nol/shared/bsp/hi/pdfs/28_07_04_climatepoll.pdf.

Kolk, A. (2008). Sustainability, Accountability and Corporate Governance: Exploring Multinationals' Reporting Practices. Business Strategy and the Environment, 18, 1-15.

Lawrence, A.T. (2002). The drivers of stakeholder engagement: reflections on the case of Royal Dutch/Shell. Journal of Corporate Citizenship, 6, 71-85. Retrieved September 1, 2009, www.wileyinterscience.wiley.com

Lincoln, Y.S. \& Guba, E.G. (2000). Paradigmatic controversies, contradictions and emerging confluences. In N.K. Denzin \& Y.S. Lincoln (Eds.), Handbook of qualitative research (2nd Ed.). New Delhi: Sage.

Lowe, D. \& Lloyd, C.R. (2001). Renewable energy systems for remote areas in Australia. Renewable Energy, 22, 369-378.

Little, J. (2001). New Rural Governance? Progress in Human Geography, 25(1), 97-102.

Long, D., A. \& Perkins, D., D. (2007). Community Social and Place Predictors of Sense of Community: A Multilevel and Longitudinal Analysis. Journal of Community Psychology, 35(5), 563-581. 
Martın, E.C., Laukamp, H., Jantsch, M., Erge, T., Thornycroft, J., De Moor, H., Cobben, S., Suna, D. \& Gaiddon, B. (2008). Interaction Between Photovoltaic Distributed Generation and Electricity Networks. Progress in Photovoltaics: Research \& Applications, 16, 629-643.

McGuirk, P.M. (2001). Situating communicative planning theory: context, power, and knowledge. Environment and Planning A, 33, 195-217.

McIntyre, J. (2004). Facilitating Critical Systemic Praxis (CSP) by Means of Experiential Learning and Conceptual Tools. Systems Research and Behavioural Science, 21, 37-61.

McKenzie, M. \& Howes, M. (2006). Remote Renewable Energy in Australia: Barriers to Uptake and the Community Engagement Imperative. Refereed paper presented to the Australian Political Studies Association Conference University of Newcastle, September 25-27.

Miller, S.I. \& Fredericks, M. (1999). How Does Grounded theory Explain? Qualitative Health Research, 9(4), 538-551.

Mouffe, C. (2000). The democratic paradox. Verso, London.

Munasinghe, M. \& Swart, R. (2005). Primer on Climate Change and Sustainable Development: Facts, Policy Analysis and Applications, Cambridge University Press: Cambridge.

Murdoch, J. (1997). The shifting territory of government: some insights from the rural white paper. Area, 29, 109-127.

Nelson, R., Howden, M. \& Smith, M.S. (2008). Using adaptive governance to rethink the way science supports Australian drought policy. Environmental Science \& Policy, 11, 588-601.

O’Hara, K. (2004). Trust-From Socrates to Spin. Cambridge: Icon Books.

O’Neill, J. (1997). "Value Pluralism, Incommensurability and Institutions." In Valuing Nature?: Ethics, Economics and the Environment. J. Foster (Ed). New York: Routledge.

Owen, A.D. (2006). Renewable energy: Externality costs as market barriers. Energy Policy, 34, 632642.

Pandey, A. (2009). Greening Garhwal through Stakeholder Engagement: the Role Ecofeminism, Community and the State in Sustainable Development. Sustainable Development, 1-8. Retrieved June 1, 2009 www.interscience.wiley.com

Pandit, N. (1996). 'The Creation of Theory: A Recent Application of the Grounded Theory Method'. The Qualitative Report, 2(4), (http://www.nova.edu/ssss/QR/QR2-4/pandit.html).

Patton, M.Q. (1990). Humanistic psychology and humanistic research. Person-Centred Review, 5 , 191-202.

Pope-Davis, D.B., Toporek, R.L., Ortega-Villalobos, L., Ligiéro, D.P., Brittan-Powell, C.S., Liu, W.M., Bashshur, M.R., Codrington, J.N. \& Liang, C.T.H. (2002). Client Perspectives of Multicultural Counseling Competence: A Qualitative Examination. The Counselling Psychologist, 30(3), 355-393.

Przeworski, A. (1998). Deliberation and ideological domination. In J. Elster (Ed.), Deliberative Democracy (pp. 140-160). Cambridge: Cambridge University Press.

Punch, K.F. (1998). Introduction to Social Research: Qualitative and Quantitative Approaches, London: Sage.

Reid, R. (2009). The Moral Imperative for Sustainable Communities. Public Management, 91(4), 2731.

Robinson, J, (2004). Squaring the circle? Some thoughts on the idea of sustainable development. Ecological Economics, 48, 369- 384

Sagoff, M. (1988). The economy of the earth. Cambridge University Press, Cambridge.

Sandelowski, M. (2000). Focus on Research Methods: Combining Qualitative and Quantitative Sampling, Data Collection, and Analysis Techniques in Mixed-Method Studies. Research in Nursing \& Health, 23, 246-255.

SEDO (Sustainable Energy Development Office). (2008). Electricity Generation from Renewable Energy, Fact Sheet, 5, Government of Western Australia. Retrieved January 20, 2009, http://www.sedo.energy.wa.gov.au/pages/publications.asp 
Stagl, S. (2006). Multicriteria evaluation and public participation: the case of UK energy policy. Land Use Policy, 23, 53-62. Retrieved August 20, 2009 www.sciencedirect.com

Stratford, E., Armstrong, D. \& Jaskolski, M. (2003). Relational spaces and the geopolitics of community participation in two Tasmanian local governments: a case for agonistic pluralism? Transactions of the Institute of British Geographers, New Series, 28(4), 461-472. Retrieved August, 7, 2009, http://www.jstor.org/stable/3804392

Strauss, A. \& Corbin, J. (1998). Basics of qualitative research: Grounded theory: Techniques and procedures for developing grounded theory. $\left(2^{\text {nd }}\right.$ Ed.). Thousand Oaks, CA: Sage.

Strauss, A. \& Corbin, J. (1990). Basics of Qualitative Research: Grounded Theory, Procedures and Techniques. Thousand Oaks, CA: Sage.

Stubbs, W. \& Cocklin, C. (2008). An Ecological Modernist Interpretation of Sustainability: the Case of Interface Inc. Business Strategy and the Environment, 17, 512-523. Retrieved, June 1, 2009, www.interscience.wiley.com

Szarka, (2004). Sustainable Development Strategies In France: Institutional Settings, Policy Style And Political Discourse. European Environment, 14, 16-29

Ward, N. \& McNicholas, K. (1998). Reconfiguring rural development in the UK: Objective 5b and the new rural governance. Journal of Rural Studies, 14, 27-39.

Webler, T., Kastenholz, H., Renn, O. (1995). Public participation in impact assessment: a social learning perspective. Environmental Impact Assessment Review 15, 443-463.

Williams, W. \& Lewis, D. (2005). Convergent interviewing: a tool for strategic investigation. Strategic Change, 14, 219-229.

Wolsink, M. (2007). Planning of renewable schemes: deliberative and fair decision-making on landscape issues instead of reproachful accusations of non-cooperation. Energy Policy, 35(5), 26922704.

Wilson, G.A. (2004). The Australian Landcare movement: towards 'post-productivist' rural governance? Journal of Rural Studies, 20, 461-484.

Zahnd, A. \& McKay, K.H. (2009). Benefits from a renewable energy village electrification system. Renewable Energy, 34, 362-368.

Zillman, John W., Warwick McKibbin, J., \& Aynsley Kellow. (2005). Uncertainty and Climate Change: The Challenge for Policy. Academy of Social Sciences. Canberra. Policy Paper 3.

\section{About the Author}

\section{Dr. Diane Costello}

Dr. Diane Costello is trained as a community psychologist and has been conducting research with Indigenous and rural communities since 1995. Her $\mathrm{PhD}$ focused on the social justice outcomes for rural communities dealing with the impacts of globalization and loss of social capital. This also involved evaluating the process and outcome of governance relations of community sustainability policies pushed by governments as a self-help solution. Diane has also worked as a consultant to undertake research with Indigenous communities looking at the cause of crime and evaluating the cultural appropriateness and public participation model reflected in the Health Service Programs. Diane was employed as a Lecturer at the School of Arts \& Sciences where she taught psychology with a focus on the dynamics of practicing in the Australia social context. The socio-political and historical antecedents related to Indigenous health and welfare including its diverse multi-cultural population were a major aspect in the curriculum set for professional practice. Diane is currently employed as an ARC Linkage Fellowship at the Alcoa Research Centre for Stronger Communities and her 
focus involves the social impacts of climate change within the energy sector for rural communities on groups who are socially and economically disadvantaged. 